\title{
Removal of Lead and Cadmium Ions from Water Using Cladophora Biomass
}

\author{
Abdulaziz N. Amro ${ }^{1 *}$, Mohammad K. Abhary ${ }^{2}$ \\ ${ }^{1}$ Chemistry Department, Faculty of Science, Taibah University, Al Madinah Al Munawwarah, \\ Kingdom of Saudi Arabia \\ ${ }^{2}$ Biology Department, Faculty of Science, Taibah University, Al Madinah Al Munawwarah, \\ Kingdom of Saudi Arabia
}

Received: 12 April 2018

Accepted: 26 August 2018

\begin{abstract}
Cladophora biomass has been treated and used for the removal of Lead and Cadmium ions from water, and the characterization of Cladophora biomass by Fourier transform infrared (FTIR) and energydispersive $\mathrm{x}$-ray analysis (EDS) indicate the presence of functional groups of different components such as polysaccharides, amino acids, fatty acids and others. Scanning electron microscopy (SEM) and surface area analysis (BET) confirm nonporous algal biomass with small surface area. The parameters affecting metal ions removal from water such as adsorbent-solution contact time, $\mathrm{pH}$ of metal ion solution, algal biomass dose and mesh sizes have been studied. Isothermal study has been applied using Freundlich and Langmuir models.
\end{abstract}

Keywords: Cladophora biomass; water treatment; lead; cadmium; isothermal study

\section{Introduction}

Deterioration of water resources due to heavy metal pollutants, such as lead and cadmium and other metals, have become an emerging concern for environmental agencies and governmental authorities around the world. The accumulation and persistence of such heavy metals in the food chain elevate its threat of toxicity, even when found at low concentrations in water $[1,2]$. The increment of heavy metals pollution comes from industrial revolution and transportation activities that contribute heavily with heavy metal discharge to the environment.

*e-mail: abdulazizamro@yahoo.com
Different methodologies have been applied to minimize heavy metals pollution in water resources, such as precipitation, coagulation [1], nanomaterials [3] ion exchange [4], adsorption [5], oxidation/reduction [6] and biosorption methods, which is being applied in this study.

In the biosorption method, pretreated natural substances such as seaweed or algae are used as sorbents of pollutants and become a promising alternative to the traditional physicochemical methods used for water treatment [7-12]. The Red Sea area features an important biodiversity hotspot for marine life organisms that is still being explored [13]. New algal species have been recorded in the western shores of Saudi Arabia over the past few decades [14, 15], especially in industrial areas such as Jeddah and Yanbu, where pollution, eutrophication and overfishing occur $[16,17]$. 
The genus Cladophora is a member of the Ulvophyceae alga class, recorded in shallow waters of Jeddah and Obhor regions on the western shores of Saudi Arabia [14]. Cladophora has many species that are difficult to classify due to its high morphological variations, which is greatly affected by age, habitat and temperature [18]. Nevertheless, the green algae species are characterized by its branchy, filamentous, long and setaceous green fronds [14] with thick cellulose layers in its cell wall [19] and growth limitation by both nitrogen and phosphorus [18]. Both micro- and macro- green algae have been used in the area as indicators for heavy metal pollution in wastewater [20] due to their ability to adsorb heavy metals from the surrounding environment [21]. Previous studies have shown that green algae possess a superior capability of heavy metal adsorption among different species collected and analyzed from the Red Sea area [22].

\section{Isotherm Models}

The importance of sorption isotherm comes from its representation of how metal ions distribute between the solution and biosorbents at equilibrium [23]. Several isothermal models were used for this purpose, including Langmuir and Freundlich, which are considered the most common models [24]. Selecting a suitable model depends on fitting the experimental data onto model equations, and the correlation coefficient helps by indicating the models that are suitable to fit the data.

\section{Langmuir Isotherm}

It is simply represented by the linear equation:

$$
\frac{C e}{Q e}=\frac{1}{X m K}+\frac{1}{X m} C e
$$

...where $\mathrm{C}_{\mathrm{e}}(\mathrm{mg} / \mathrm{L})$ is the metal ion concentration at equilibrium, $Q_{e}(\mathrm{mg} / \mathrm{g})$ is the amount of metal ion adsorbed per gram adsorbent, and $\mathrm{Xm}$ and $\mathrm{k}$ are the Langmuir constants representing the sorption capacity and rate of sorption, respectively [23].

\section{Freundlich Isotherm}

The linear equation of the Freundlich model [23] is:

$$
\ln Q e=\ln K f+\frac{1}{n} \ln C e
$$

In this equation; $Q_{e}$ is the amount of metal ion adsorbed at equilibrium $(\mathrm{mg} / \mathrm{g})$ and $\mathrm{Ce}(\mathrm{mg} / \mathrm{L})$ is the metal ion concentration at equilibrium. KF and $\mathrm{n}$ are Freundlich equation constants, where $n$ value indicates how favorable the sorption process and KF represents the sorption capacity of the adsorbent.

In the present study, treated Cladophora sp. are characterized for its ability in lead and cadmium ion removal, considering the parameters affecting the removal of heavy metals from water such as $\mathrm{pH}$, algal biomass dose and mesh size. The adsorption of metal ions on adsorbent is illustrated by the isothermal study.

\section{Experimental}

\section{Cladophora Sampling and Sample Preparation}

Samples of Cladophora sp. green algae were collected from three different locations, heavily contaminated with boat oil and wastewater, at Yanbu in fall 2016. The algae were kept in plastic bags at a cool temperature and sent to the lab. Samples were immediately soaked and washed with tap water and then rewashed three times with distilled water. The biomass was dried overnight in a $45^{\circ} \mathrm{C}$ oven and ground using a commercial blender. Powdered Cladophora biomass was sieved through different mesh sizes $<0.125,0.125-0.212,0.212-0.5$, 0.5-1.0 and 1.0-2.0 $\mathrm{mm}$.

\section{Chemicals and Equipment}

All glass and plasticware used were previously soaked overnight in $10 \%$ nitric acid, rinsed with distilled water, and finally with deionized water. Cadmium stock solution 1000 ppm was prepared from cadmium nitrate (Sigma-Aldrich). Lead stock solution 1000 ppm was prepared from lead nitrate (Fluka). Nitric acid was bought from Riedel-de'Haën (65\%, Puriss, Germany), while $\mathrm{AA} \mathrm{Cd}$ and $\mathrm{Pb}$ elements standards were bought from Panreac $\left(1000 \mu \mathrm{g} \mathrm{mL}^{-1}\right)$. Metal ions determinations were done using atomic absorption spectroscopy (Agilent Technology, 200 series). 0.1M $\mathrm{HNO}_{3}$ and $0.2 \mathrm{M} \mathrm{NaOH}$ were used to adapt the required $\mathrm{pH}$.

Scanning electron microscopy (SEM) was performed using a NOVA NANO SEM instrument. Elemental analysis was conducted using energy-dispersive X-ray spectroscopy (EDS) of Superscan SSX-550 Shimadsu Company. Fourier transfer infra-red (FTIR) characterization was done by (IR Affinity-1) Shimadsu Company and surface area by BET (Micromeritics ASAP 2020).

\section{Results and Discussions}

\section{Algal Biomass Characterization}

\section{Fourier Transfer Infra-Red (FTIR)}

FTIR spectra (Fig. 1) shows the functional groups that are responsible candidates for metals adsorption such as hydroxyl, carbonyl, sulfonate and carboxylic. According to the FTIR spectra in (Fig. 1), peaks show that algal biomass sample contains a mixture of different components such as polysaccharides, amino acids, fatty acids and others. Bands at 3618 


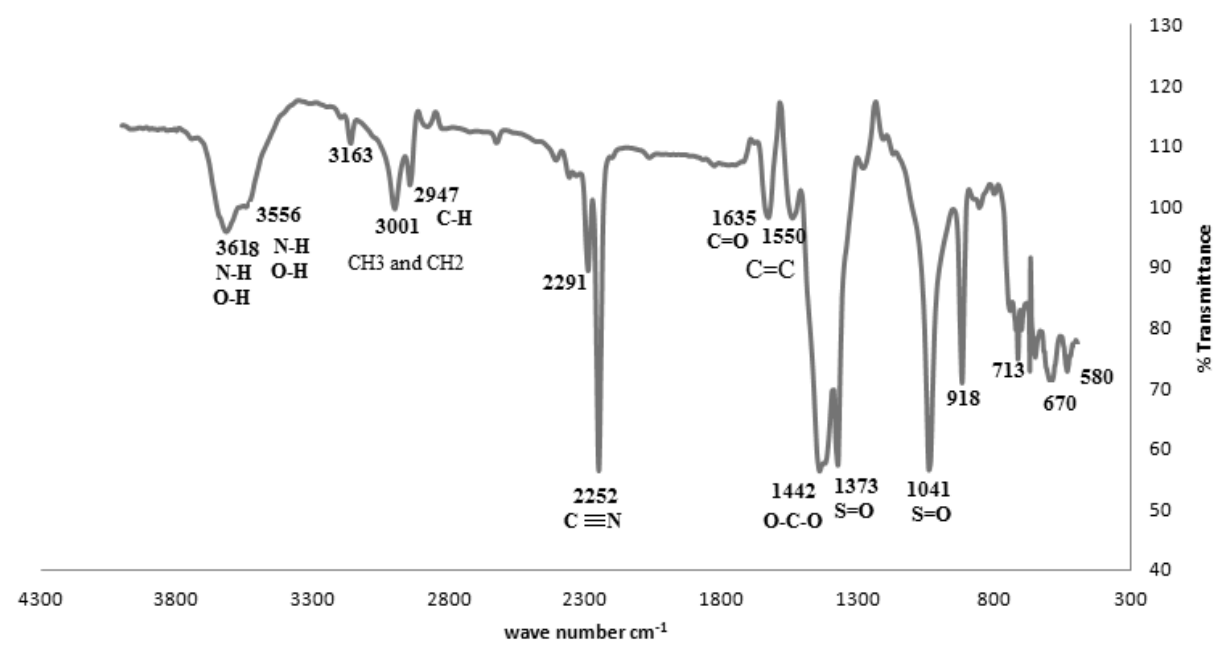

Fig. 1. FTIR spectra of Cladophora biomass.

and $3556 \mathrm{~cm}^{-1}$ indicate the presence of $\mathrm{O}-\mathrm{H}$ and $\mathrm{N}-\mathrm{H}$ stretching vibrations, whose groups resemble the presence of amino acids [25]. The presence of chlorophyll groups is confirmed by $\mathrm{CH} 3$ and $\mathrm{CH} 2$ stretching bands at 2947 and $2893 \mathrm{~cm}^{-1}[25]$. 2337, $2360 \mathrm{~cm}^{-1}$ stands for C-O and P-H stretching bands of carboxylic group and phosphine, respectively. The sharp peak at $2252 \mathrm{~cm}^{-1}$ stand for $\mathrm{CN}$ bond of acetonitrile added to the sample for FTIR analysis. The $1635 \mathrm{~cm}^{-1}$ peak is due to $\mathrm{C}=\mathrm{O}$ stretching and $1550 \mathrm{~cm}^{-1}$ is due to $\mathrm{C}=\mathrm{C}$ stretching, which is indicative of the presence of pectin and lignin, respectively. $1373 \mathrm{~cm}^{-1} 1041 \mathrm{~cm}^{-1}$ peaks are stretching bands of $\mathrm{S}=\mathrm{O}$ related to sulfonamides and sulfone, respectively. The $1442 \mathrm{~cm}^{-1}$ shows a peak due to $\mathrm{O}-\mathrm{C}-\mathrm{O}$ symmetric stretching vibration amino acids [26]. The appearance of $670 \mathrm{~cm}^{-1}$ reveals $\mathrm{C}-\mathrm{H}$ bonds of aromatic or vinyl compounds [27]. Strong $920 \mathrm{~cm}^{-1}$ stand for P-O-C stretching, and the weak absorption bands observed near 580 and $670 \mathrm{~cm}^{-1}$ are due to C-S and $\mathrm{C}=\mathrm{S}$ stretching vibrations (sulfides) [27].

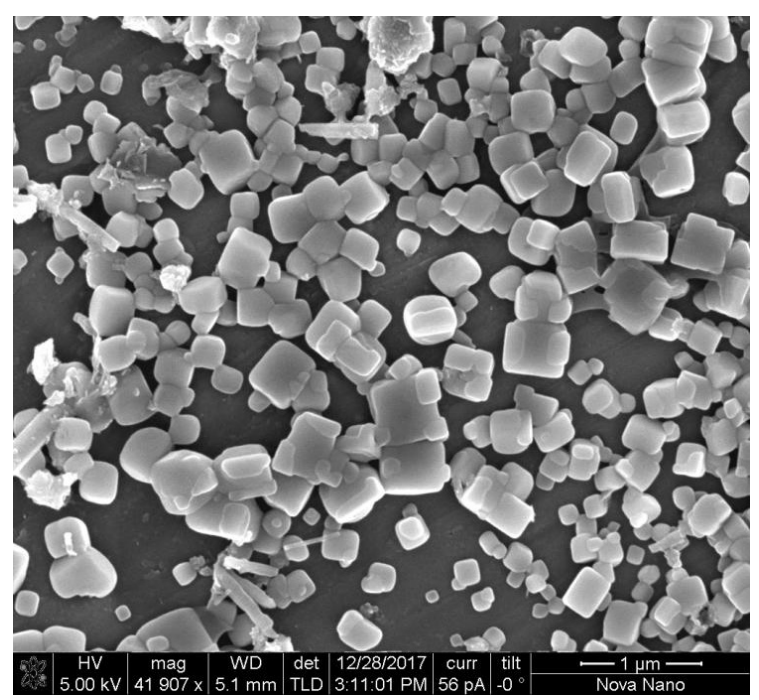

Fig. 2. SEM image of Cladophora biomass.

\section{Scanning Electron Microscopy (SEM) and BET (Surface Area)}

BET surface area analysis of Cladophora showed that the surface area is $1.7062 \mathrm{~m}^{2} / \mathrm{g}$, this small surface area synchronized with the scanning electron microscopy SEM image (Fig. 2), which showed that Cladophora algal biomass is nonporous material.

\section{Energy-Dispersive x-ray Analysis (EDS)}

EDS analysis results in (Table 1 and Fig. 3) shows the presence of $\mathrm{O}, \mathrm{C}, \mathrm{N}, \mathrm{S}$ and $\mathrm{P}$ elements, which synchronizes with the FTIR analysis data and illustrates the functional groups that should contain these elements, in addition to other alkali and alkaline earth metals that are usually available in algal biomass [24].

\section{Factors Affecting Metal Ion Removal Study}

\section{Effect of Contact Time}

The effect of contact time on the removal of metal ions are shown in (Fig. 4). The equilibrium time was around 45 and 60 minutes for $\mathrm{Cd}$ and $\mathrm{Pb}$ ions, respectively. Generally, the equilibrium time depends on

Table 1. EDS results of Cladophora biomass.

\begin{tabular}{|c|c|c|c|c|c|}
\hline Element & $\begin{array}{c}\text { Weight } \\
\%\end{array}$ & $\begin{array}{c}\text { Atom } \\
\%\end{array}$ & Element & $\begin{array}{c}\text { Weight } \\
\%\end{array}$ & $\begin{array}{c}\text { Atom } \\
\%\end{array}$ \\
\hline $\mathrm{O}$ & 36.73 & 40.29 & $\mathrm{Cl}$ & 10.09 & 4.94 \\
\hline $\mathrm{Na}$ & 7.76 & 5.92 & $\mathrm{~N}$ & 4.5 & 4.91 \\
\hline $\mathrm{Mg}$ & 3.79 & 2.73 & $\mathrm{~K}$ & 2.75 & 1.23 \\
\hline $\mathrm{Al}$ & 1.36 & 0.88 & $\mathrm{Ca}$ & 3.25 & 1.42 \\
\hline $\mathrm{Si}$ & 2.1 & 1.31 & $\mathrm{Fe}$ & 0.59 & 0.19 \\
\hline $\mathrm{S}$ & 3.2 & 1.75 & $\mathrm{P}$ & 0.51 & 0.34 \\
\hline
\end{tabular}




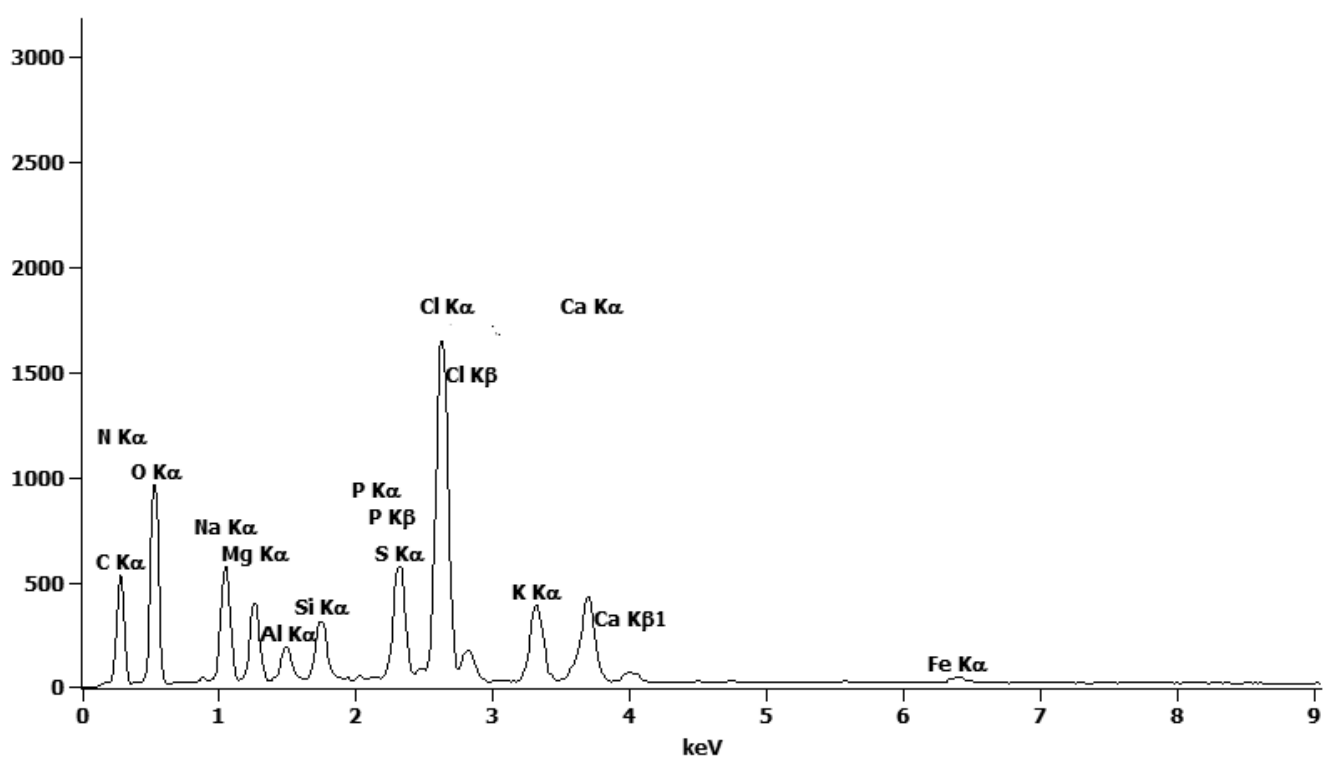

Fig. 3. EDS spectra of Cladophora biomass.

the nature of adsorbent and the availability of sorption sites.

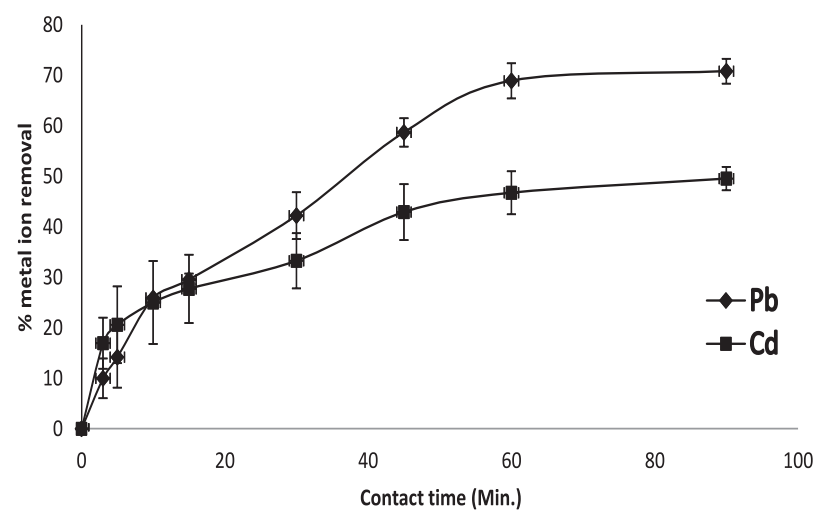

Fig. 4. Effect of contact time on metal ion removal (mean \pm RSD) (50 mL, 50 ppm) using Cladophora (0.2 g, 0.212-0.5 mm)

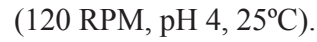

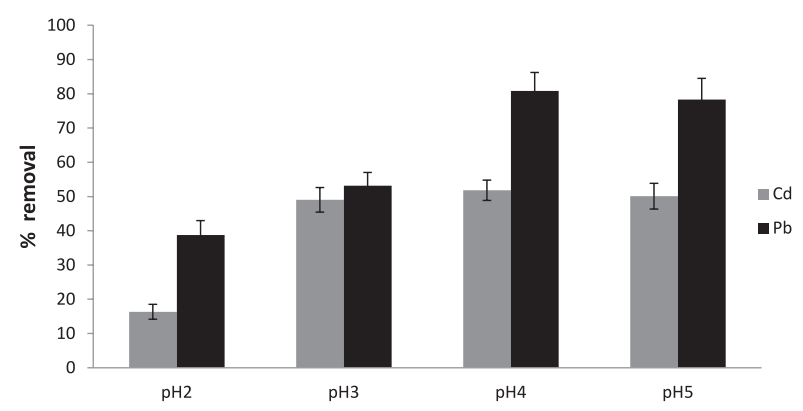

Fig. 5. Effect of solution $\mathrm{pH}$ on metal ion removal (mean \pm RSD) (50 mL, $50 \mathrm{ppm})$ using Cladophora (0.2 g, 0.212-0.5 mm) (120 RPM, $60 \mathrm{Min}, 25^{\circ} \mathrm{C}$ ).

\section{Effect of $\mathrm{pH}$}

The effect of metal ion solution $\mathrm{pH}$ has been studied in the range $\mathrm{pH}$ (2-5), higher $\mathrm{pH}$ not applied since higher $\mathrm{pH}$ values metal hydroxide form (Fig. 5) shows clearly that metal ion removal increased significantly between $\mathrm{pH} 2$ and 3 for both $\mathrm{Cd}$ and $\mathrm{Pb}$ ions, and for $\mathrm{Cd}$ ion there no significant difference between $\mathrm{pH} 3,4$ and 5 with removal percentage reaching around $50 \%$. On the other hand, $\mathrm{Pb}$ ion removal reaches the value of $80 \%$ at $\mathrm{pH} 4$, with no significant difference from $\mathrm{pH} 5$.

\section{Effect of Algal Biomass Dosage}

Metal ion removal has been studied by a wide range of algal biomasses, as shown in (Fig. 6), the maximum dose used is $0.75 \mathrm{~g}$, since at higher doses the solution becomes like emulsion. As shown in (Fig. 6), increasing doses have no significant effect on $\mathrm{Pb}$ ion removal, which falls in the range of 70 to $80 \%$.

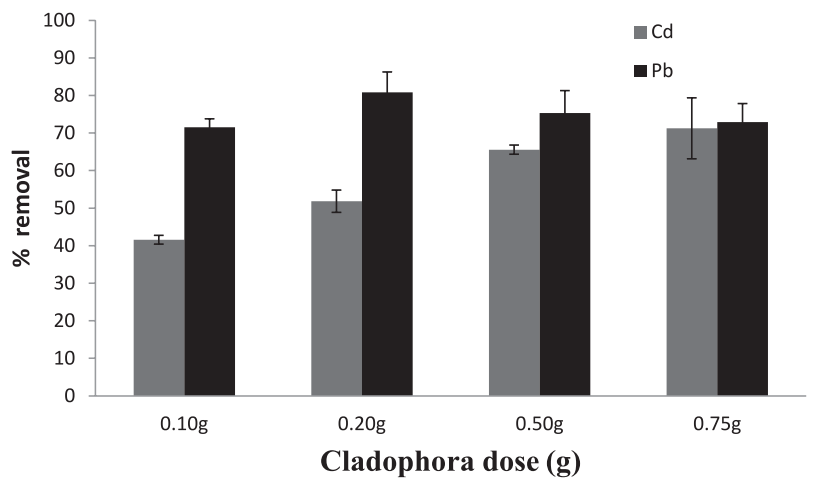

Fig. 6. Effect of Cladophora dose $(0.212-0.50 \mathrm{~mm})$ on metal ion removal (mean $\pm \mathrm{RSD}$ ) (50 mL, $50 \mathrm{ppm}, \mathrm{pH}$ 4) (120 RPM, $\left.60 \mathrm{Min}, 25^{\circ} \mathrm{C}\right)$. 


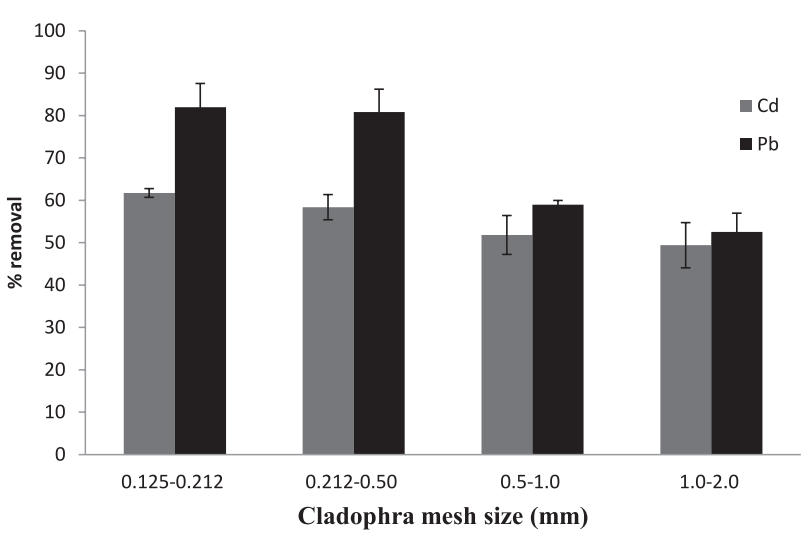

Fig. 7. Effect of Cladophora mesh size $(0.20 \mathrm{~g})$ on metal ion removal (mean $\pm \mathrm{RSD})(50 \mathrm{~mL}, 50 \mathrm{ppm}, \mathrm{pH}$ 4) (120 RPM, $\left.60 \mathrm{Min}, 25^{\circ} \mathrm{C}\right)$

For $\mathrm{Cd}$ ion removal increases clearly as dose increases, $\mathrm{Cd}$ ion removal reaches around $70 \%$ for $0.75 \mathrm{~g}$ dose.

\section{Effect of Algal Biomass Mesh Size}

Using different mesh sizes reflects directly on surface area, which increases as mesh size decreases. $\mathrm{Pb}$ ion removal increases with the decrease of mesh size, as shown in (Fig. 7). On the other hand, Fig. 7 shows no significant difference in $\mathrm{Pb}$ ion removal between $(0.125-0.212 \mathrm{~mm})$ and $(0.212-0.50 \mathrm{~mm})$ with around $80 \%$, and $\mathrm{Pb}$ ion removal decreases to around $55 \%$ at higher mesh sizes. On the other hand, the removal of $\mathrm{Cd}$ ion reaches around $60 \%$ at mesh sizes less than $0.5 \mathrm{~mm}$, which is higher but not significantly different from mesh sizes 0.5-2.0 $\mathrm{mm}$, which reach around 50\% $\mathrm{Cd}$ ion removal, as shown in Fig. 7.

\section{Adsorption Isotherms}

Adsorption isothermal study has been conducted in order to estimate the maximum adsorption capacity of algal biomass, furthermore isothermal study results predict how metal ions adsorbed on algal biomass surface. Initial metal ion concentrations used were 100 to $500 \mathrm{mg} \backslash \mathrm{L}$.

According to the trend line equations in (Fig. 8) that represents Langmuir and Freundlich for $\mathrm{Cd}$ and $\mathrm{Pb}$ ions, $\mathrm{R}^{2}$ values for Langmuir are higher than Freundlich isotherm for both ions, which indicated the metal ions adsorbed as a homogenous monolayer on algal biomass surface. Sorption capacities according to Langmuir isotherm equation are 60.97 and $18.87 \mathrm{mg} / \mathrm{g}$ algal biomass for $\mathrm{Pb}$ and $\mathrm{Cd}$ ion, respectively.

\section{Effect of Contact Time and Adsorption Kinetic Models}

(Fig. 9a) shows the effect of contact time between Cladophora biomass and metal ions on the adsorption capacity, and it is clear from Fig. 9a) that the adsorption of both metal ions increases sharply in the first 30 minutes. Furthermore, adsorption reaches equilibrium plateau after one hour contact time for both metal ions.

Adsorption kinetic models were applied to study how metal ions are adsorbed on the Cladophora biomass surface.

The first-order model for physisorption process, in this model the adsorption rate relates to the vacant
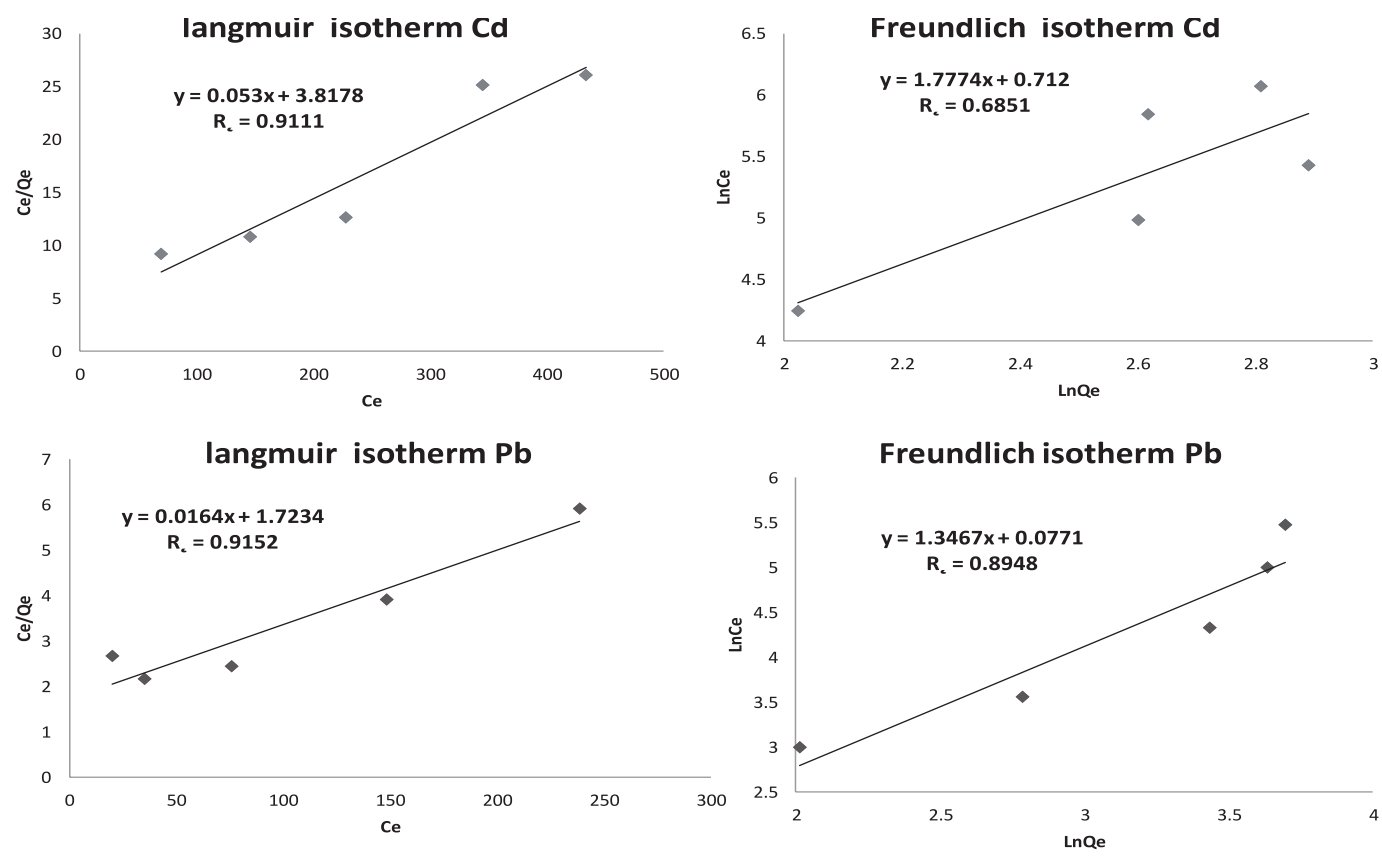

Fig. 8. Langmuir and Freundlich isotherms of $\mathrm{Pb}$ and $\mathrm{Cd}$ ions, $0.20 \mathrm{~g}$ Algal biomass, $50-500 \mathrm{mg} / \mathrm{L}$ initial concentration $(50 \mathrm{~mL}$, $\mathrm{pH} 4,120$ RPM, 60 Min, $25^{\circ} \mathrm{C}$ ). 

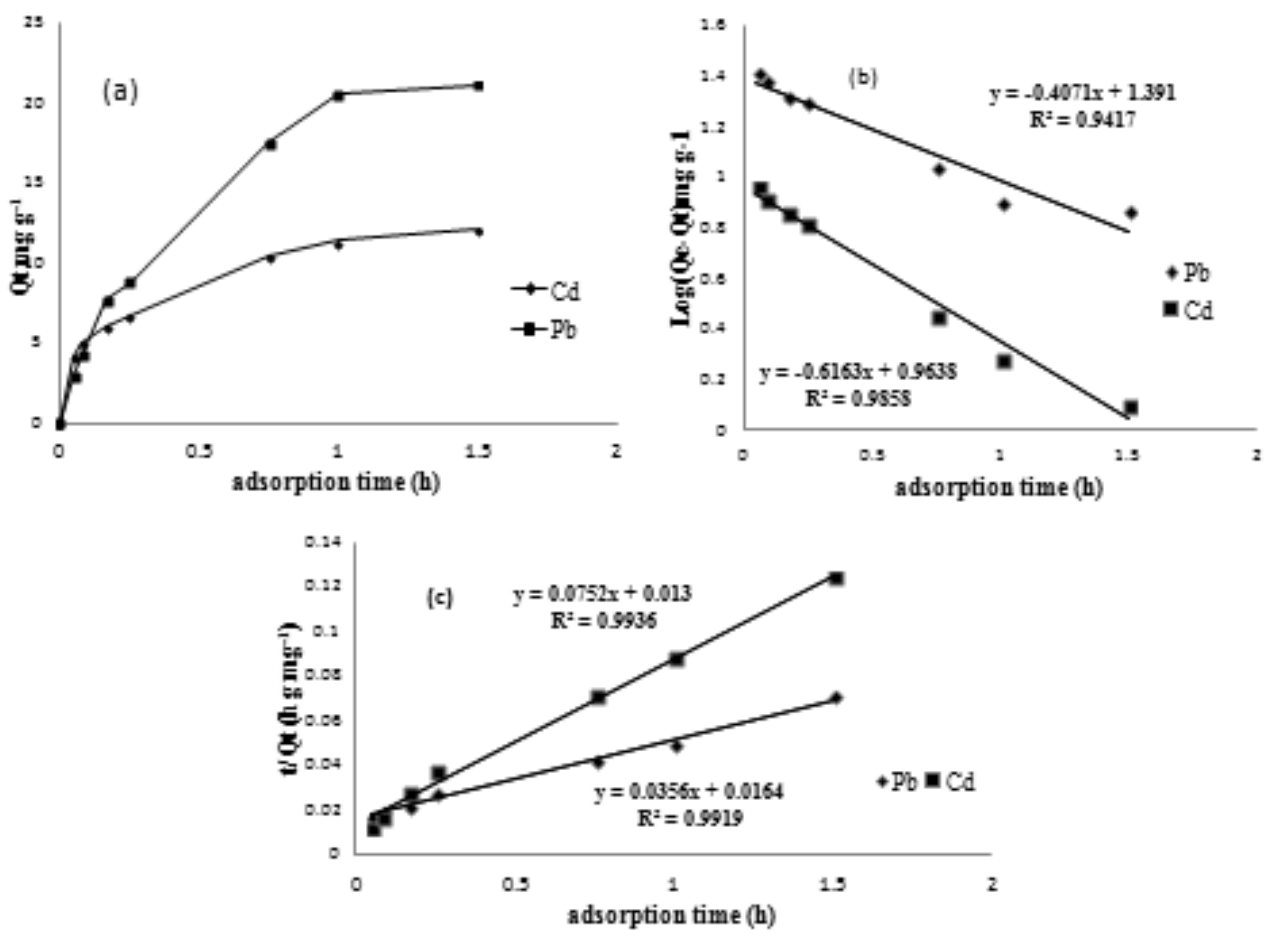

Fig. 9. a) Effect of time on the adsorption capacity of $\mathrm{Cd}$ and $\mathrm{Pb}$ ions on Cladophora biomass, b) first-order kinetic model, c) secondorder kinetic model.

adsorptive sites on the adsorbent [28, 29]. The linear form of this model can be expressed by the following equation:

$$
\log (\mathrm{Q} e-\mathrm{Qt})=\log \mathrm{Qe}-\frac{k 1 t}{2.303}
$$

...where Qt is the adsorption capacity at a certain time $\mathrm{t}\left(\mathrm{mg} \mathrm{g}^{-1}\right)$ and $\mathrm{k} 1$ is the first-order rate constant $\left(\mathrm{h}^{-1}\right)$. From the kinetic model data in Table 2 (Fig. 9b) for the adsorption of $\mathrm{Pb}$ and $\mathrm{Cd}$ ions, it can be concluded that data are poorly fitted to the kinetic model for both metal ions.

However, the second-order kinetic model (Fig. 9c), which expresses the presence of chemisorption process, is related to the difference between the equilibrium vacant adsorptive sites and the occupied sites [28, 30]. The second-order kinetic model can be expressed by the following linear equation:

$$
\frac{t}{Q t}=\frac{1}{k 2 Q e^{2}}+\frac{t}{Q e}
$$

...where $\mathrm{k}_{2}$ is the second-order rate constant $\left(\mathrm{g} \mathrm{mg}^{-1} \mathrm{~h}^{-1}\right)$. Data shown in Table 2 indicated that the adsorption of $\mathrm{Pb}$ and $\mathrm{Cd}$ ions fit with the second-order kinetic model, with correlation coefficient $\left(\mathrm{R}^{2}>0.99\right)$ for both metal ions. Furthermore, differences between Qe calc and Qe exp are lower in the second-order kinetic model than the first-order kinetic model for $\mathrm{Cd}$ ion, counter to
$\mathrm{Pb}$ ion. According to the fitness of the data to the secondorder kinetic model, the adsorption of $\mathrm{Pb}$ and $\mathrm{Cd}$ ions by Cladophora biomass may be chemisorption.

\section{Conclusion}

The ability of Cladophora biomass to remove metal ions from water samples reached $80 \%$ and $50 \%$ of $\mathrm{Pb}$ and $\mathrm{Cd}$ ions, respectively. Moreover, metal ion removal reached equilibrium within 60 minutes contact time for both $\mathrm{Pb}$ and $\mathrm{Cd}$ ions. The optimum $\mathrm{pH}$ of metal ion solutions is 4 for both $\mathrm{Cd}$ and $\mathrm{Pb}$. Nevertheless, algal biomass dose of $0.20 \mathrm{~g}$ was shown to be the optimum

Table 2. First- and second-order kinetic models for the adsorption of lead and cadmium ions on Cladophora biomass.

\begin{tabular}{|c|c|c|c|c|}
\hline \multirow{2}{*}{ Metal ion } & \multicolumn{4}{|c|}{ First order kinetic model } \\
\cline { 2 - 5 } & $\begin{array}{c}\mathrm{Q}_{\mathrm{e} \text { exp }} \\
\left(\mathrm{mg} \mathrm{g}^{-1}\right)\end{array}$ & $\begin{array}{c}\mathrm{Q}_{\mathrm{e}, \text { calc }} \\
\left(\mathrm{mg} \mathrm{g}^{-1}\right)\end{array}$ & $\mathrm{k}_{1}\left(^{\mathrm{h}-1}\right)$ & $\mathrm{R}^{2}$ \\
\hline $\mathrm{Pb}$ & 20.56 & 24.60 & 0.9375 & 0.9417 \\
\hline $\mathrm{Cd}$ & 12.07 & 9.20 & 1.419 & 0.9858 \\
\hline & \multicolumn{4}{|c|}{ Second order kinetic model } \\
\hline $\mathrm{Pb}$ & 20.56 & 28.4 & 0.0348 & 0.9919 \\
\hline $\mathrm{Cd}$ & 12.07 & 13.33 & 0.0741 & 0.9936 \\
\hline
\end{tabular}


dose for $\mathrm{Pb}$ ion removal, and the $0.50 \mathrm{~g}$ dose showed better performance for $\mathrm{Cd}$ ion removal. Smaller algal biomass mesh sizes showed better $\mathrm{Pb}$ ion removal than bigger ones, and no significant effect of mesh sizes for $\mathrm{Cd}$ ion removal. Isothermal study results correlate with the Langmuir model for both $\mathrm{Pb}$ and $\mathrm{Cd}$ ions, which means that metal ions form a homogenous monolayer on algal biomass surface. Adsorption kinetic study showed experimental adsorption capacity of 20.56 and 12.07 $\mathrm{mg} / \mathrm{g}$ algal biomass for $\mathrm{Pb}$ and $\mathrm{Cd}$ ions, respectively. Furthermore, kinetic models indicated that both metal ions fit the second-order kinetic model, so adsorption by Cladophora biomass may be chemisorption.

\section{Acknowledgements}

The authors thank the Dean of Scientific Research at Taibah University for financial support under contract No. 6308/1435.

\section{Conflict of Interest}

The authors have not declared any conflict of interest.

\section{References}

1. PENG Q., CHEN W., WU L., BAI L. The Uptake, Accumulation, and Toxic Effects of Cadmium in Barnyardgrass (Echinochloa crus-galli). Polish Journal of Environmental Studies. 26 (2) 779, 2017.

2. ABU AL-RUB F.A., El-NAAS M.H., ASHOUR I., AlMARZOUKI M. Biosorption of copper on Chlorella vulgaris from single, binary and ternary metal aqueous solutions. Process Biochemistry. 41, 457, 2006.

3. AMIN M.T., AlAZBA A.A., MANZOOR U. A Review of Removal of Pollutants from Water/Wastewater Using Different Types of Nanomaterials. Advances in Materials Science and Engineering, 1, 1, 2014.

4. GAIKWAD R.W., SAPKAL V.S., SAPKAL R.S. Ion exchange system design for removal of heavy metals from acid mine drainage wastewater. Acta Montanistica Slovaca. 15 (4) 298, 2010.

5. AMRO A.N., YOUSEF R.I., MUSLEH S.M. Chemical Treatment of Jordanian Zeolitic Tuff Using Dimethyl Sulfoxide and Thiourea. Asian Journal of Chemistry. 21, (4) $2973,2009$.

6. CHAKRABARTI S., CHAUDHURI B., BHATTACHARJEE S., RAY A.K., DUTTA B.K. Photoreduction of hexavalent chromium in aqueous solution in the presence of zinc oxide as semiconductor catalyst. Chemical Engineering Journal. 153, 86, 2009.

7. SAEED A., IQPAL M., AKHTAR M.W. Removal and recovery of lead (II) from single and multi metal $(\mathrm{Cd}, \mathrm{Cu}$, $\mathrm{Ni}, \mathrm{Zn}$ ) solutions by crop milling waste (black gram husk). J. Hazard. Mater. 117, 65, 2005.

8. GONG R., DING Y.D., LIU H., CHEN Q., LIU Z. Lead biosorption by intact and pretreated spirulina maxima biomass. Chemosphere. 58, 125, 2005.
9. ABU AL-RUB F.A., El-NAAS M.H., BENYAHYA F., ASHOUR I. Biosorption of nickel on blank alginate beads, free and immobilized algal cells. Process Biochemistry. 39, 1767, 2004.

10. DAVIS T., VOLESKY B., MUCCI A. A review of the biochemistry of heavy metal biosorption by brown algae. Water Res. 37, 4311, 2003.

11. DENG Y., WANG L., LUO K., PENG D., JIANG H., JIN C., ZHOU X., BAI L. Screening and identifying a cadmium-resistant fungus and characterizing its cadmium adsorption. Polish Journal of Environmental Studies. 26 (3) 1011, 2017.

12. AMIN M.T., AlAZBA A.A., AMIN M.N. Absorption behaviors of copper, lead, and arsenic in aqueous solution using date palm fibers and orange peel: kinetics and thermodynamics. Polish Journal of Environmental Studies. 26 (2) 543, 2017.

13. SONNEWALD M., El-SHERBINY M.M. Editorial: Red Sea biodiversity, Marin Biodiversity. 47, 991, 2017.

14. ALEEM A.A. Marine Algae from Obhor, in the vicinity of Jeddah, Saudi Arabia. Bulletin Faculty of Science K.A. U. Jeddah. 2, 539, 1978.

15. HARIRI M. The present status of the Red Sea coral reefs between Haql and Yanbu, Saudi Arabia. Life Science Journal. 9 (4) 3852, 2012.

16. PAIMPILLIL J., SE J., DAHALAWI M. Impact of treated industrial effluents on Yanbu (Red Sea) Coral Reefs and the Efficiency of Coastal Ecosystems Conservation. The Changing Coast. EUROCOAST / EUCC, Porto - Portugal Ed. EUROCOAST - Portugal. 311, 2002.

17. ERTFEMEIJER P. Seawater intake and outfall channel and thermal pollution study in northern and southern sector at MYAS (Yanbu), Saudi Arabia. Report prepared for the Saudi Consulting Services. 2006.

18. GESTINARI L.M., SONIA P.M., YOCIE Y.V. Distribution of Cladophora Species (Cladophorales, Chlorophyta) along the Brazilian Coast. Phytotaxa. 14, 22, 2010.

19. SARGIN I., ARSLAN G., KAYA M. Efficiency of chitosan-algal biomass composite microbeads at heavy metal removal. Reactive and Functional Polymers. 98, 38, 2016.

20. Al-HOMAIDAN A., Al-GHANAYEM A., ALKHALIFAH A. Green algae as bio indicators of heavy metal pollution in Wadi Hanifah stream, Riyadh, Saudi Arabia. International Journal of Water Resources and Arid Environments. 1 (1) 10, 2011.

21. DWIVEDI S. Bioremediation of heavy metal by algae: current and future perspective. J. Adv. Lab. Res. Bio. 3 (3) 228, 2012.

22. El-NAGGAR M., Al-AMOUDI O. Heavy metal levels in several species of marine algae from the red sea of Saudi Arabia. Journal of King Abdulaziz University: Science. 1, 5, 1989.

23. HARARAH M.A., Al-NASIR F., El-HASAN T., AL-MUHTASEB A.H. Zinc adsorption-desorption isotherms: possible effects on the calcareous vertisol soils from Jordan, Environ Earth Science. 65, 2079, 2012.

24. AHMADY S., MOHAMMADI M. Biosorption of Copper Ions by Marine Brown Alga Fucus vesiculosus, Journal of Biological and environmental science. 5 (15), 121, 2011.

25. KANNAN S. FT-IR and EDS analysis of the seaweeds Sargassum wightii (brown algae) and Gracilaria corticata (red algae). International Journal of Current Microbiological Application Science. 3 (4), 341, 2014. 
26. MARIA A.P.C., MAYER D.A. POZDNIAKOVA T.A., MAZUR L.P., BOAVENTURA R.A.R., DE SOUZA A.A.U., DE SOUZA S.M.A., VILAR V.J.P. Removal of Metal Ions from a Petrochemical Wastewater using Brown Macro-algae as Natural Cation exchanger. Chemical Engineering Journal. 286, 1, 2016.

27. SON E.B., POO K.M., CHANG J.S., CHAE K. Heavy metal removal from aqueous solutions using engineered magnetic biochars derived from waste marine macro-algal biomass. J. Science of the Total Environment. 615, 161, 2018.

28. AL HAMOUZ O.C.S., AKINTOLA O.S. Chemistry Removal of lead and arsenic ions by a new series of aniline based polyamines. Process Safety and Environmental Protection. 106, 180, 2017.

29. SHEN S., GUISHEN L., PAN T., HE J., GUO Z. Selective adsorption of $\mathrm{Pt}$ ions from chloride solutions obtained by leaching chlorinated spent automotive catalysts on ion exchange resin Diaion WA21J. J. Colloid Interface Sci. 364, 482, 2011.

30. SHAABAN A.F., FADEL D.A., MAHMOUD A.A., ELKOMY M.A., ELBAHY S.M. Synthesis of a new chelating resin bearing amidoxime group for adsorption of $\mathrm{Cu}$ (II), $\mathrm{Ni}$ (II) and $\mathrm{Pb}$ (II) by batch and fixed-bed column methods. J. Environ. Chem. Eng. 2, 632, 2014. 